\begin{tabular}{|l|l|}
\hline JITAS & $\begin{array}{l}\text { JANHUS Journal of Animal Husbandry Science } \\
\text { Jurnal IImu Peternakan } \\
\text { Fakultas Pertanian, Universitas Garut } \\
\text { P ISSN : 2548-7914, E ISSN : 2775-0469 }\end{array}$ \\
\hline
\end{tabular}

\title{
PENGARUH IMBANGAN RUMPUT DAN KONSENTRAT TERHADAP UKURAN TUBUH DOMBA GARUT JANTAN UMUR LIMA SAMPAI DELAPAN BULAN
}

\section{(Effect of Grass Balance and Concentrate on Body Size for Garut Sheep Ages Five to Eight Monts)}

\author{
Ahmad Maulana ${ }^{1}$; Ibrahim Hadist ${ }^{2}$; Budi Ayuningsih ${ }^{3}$ \\ ${ }^{1}$ Alumni Program Studi Peternakan, Fakultas Pertanian, Universitas Garut \\ ${ }^{2}$ Program Studi Peternakan, Fakultas Pertanian, Universitas Garut \\ ${ }^{3}$ Fakultas Peternakan, Universitas Padjadjaran \\ email: \\ 1 ahmadmaulana.kk@gmail.com \\ ${ }^{2}$ hadistibra@uniga.ac.id
}

\begin{abstract}
Abstrak
Penelitian ini bertujuan untuk mengetahui imbangan rumput dan konsentrat terhadap ukuran tubuh Domba Garut umur lima sampai delapan bulan. Penelitian dilaksanakan pada bulan Juni sampai Agustus 2019 di UPTD BPPTDK Margawati Garut. Metode yang digunakan adalah metode eksperimental menggunakan Rancangan Acak Lengkap (RAL) dengan tiga perlakuan dan enam ulangan. Ternak percobaan yang digunakan yaitu 18 ekor Domba Garut jantan umur lima sampai delapan bulan. Hasil penelitian menunjukan bahwa P3 (40\% Rumput : 60\%), berpengaruh terhadap lebar dada dan panjang badan akan tetapi tidak mempengaruhi terhadap lingkar dada dan tinggi pundak.
\end{abstract}

Kata Kunci : Rumput, Konsentrat, Ukuran Tubuh, Domba Garut.

\section{Abstract}

This study aims to determine the balance of grass and concentrate on body size of Garut Sheep aged five to eight months. The study was conducted in June to August 2019 at UPTD BPPTDK Margawati Garut. The method used is an experimental method using a completely randomized design (CRD) with three treatments and six replications. The experimental animals used were 18 male Garut sheep aged five to eight months. The results showed that P3 (40\% Grass: 60\%), affected the width of the chest and body length but did not affect the chest circumference and shoulder height.

Keywords : Grass, Concentrate, Body Size, Garut Sheep 


\section{Pendahuluan}

Domba Garut merupakan ternak ruminansia kecil yang banyak dipelihara oleh masyarakat, karena pemeliharaannya yang tidak begitu sulit, dan sudah turun temurun dipelihara di Indonesia. Selain itu Domba Garut juga merupakan aset plasma nutfah Jawa Barat, yang berpotensi baik untuk dikembangkan sebagai sumber protein hewani. Populasi ternak khususnya domba meningkat dari tahun ke tahun, di daerah provinsi Jawa Barat pada tahun 2014 sebesar 10.612.726, tahun 2015 sebesar 11.575.359, tahun 2016 sebesar 12.462.091 dan tahun 2017 sebesar 10.714.663 dengan pencapaian pertumbuhan sebesar 7,66 \% (Direktorat Jenderal Peternakan dan Kesehatan Hewan, 2018). Peningkatan populasi Domba Garut sangat didukung oleh ketersediaan sumber bahan pakan seperti rumput dan konsetrat untuk kehidupan Domba Garut tersebut.

Kebutuhan nutrisi Domba Garut khususnya rumput dan konsentrat digunakan hidup pokok dan pertumbuhan. Ketersediaan rumput dan konsetrat yang seimbang akan memberikan pengaruh yang baik pada ternak, yaitu untuk meningkatkan produksi ternak berupa konsumsi ransum yang optimal, pertambahan ukuran tubuh Domba Garut pada domba lepas sapih. Pada dasarnya domba lepas sapih sangat membutuhkan asupan nutrisi yang baik untuk pertumbuhan ukuran badan domba lepas sapih. Karena domba lepas sapih dalam periode ini masa pertumbuhan sangat pesat jadi dibutuhkan ransum yang seimbang untuk tubuhnya.

Ukuran-ukuran tubuh ternak yang dapat diamati guna menentukan adanya pertambahan obot badan adalah lebar dada, tinggi pundak, lingkar dada dan panjang badan. Meningkatnya pertambahan ukuran-ukuran tubuh tersebut akan memberikan informasi kualitas dari ransum untuk Domba Garut jantan.

\section{Metodologi}

\subsection{Waktu dan Tempat}

Penelitian dilaksanakan selama 3 bulan dari bulan Mei sampai Agustus 2019. Lokasi di UPTD BPPTDK (Unit Pelaksanaan Teknis-Balai Pengembangan Perbibitan Ternak Domba dan Kambing) Margawati Kabupaten Garut Jawa Barat.

\subsection{Objek dan Metoda Penelitian}

\section{Obyek Penelitian}

Ternak yang digunakan dalam penelitian adalah ternak Domba Garut jantan lepas sapih sebanyak 18 ekor, dengan kisaran umur 5-8 bulan, memiliki bobot badan kurang lebih 12-15 kg.

\section{Metode Penelitian}

Metode yang dilakukan adalah metode eksperimental dengan pelaksanaan penelitian dilakukan selama 3 bulan dengan beberapa tahapan mulai dari persiapan kandang individu hingga tahapan pra penelitian selama 2 minggu.

\section{Tahap Pemeliharaan}


Pemeliharaan dilakukan selama 3 bulan, selama pemeliharaan pemberian ransum pada domba yaitu sebagai berikut berdasarkan (Bahan Kering): $\mathrm{P} 1$ : pemberian rumput $80 \%$ dengan konsentrat $20 \%$, P2: pemberian rumput $60 \%$ dengan konsentrat $40 \%, \mathrm{P} 3$ : pemberian rumput $40 \%$ dengan konsentrat $60 \%$.

Pemberian ransum dibagi menjadi 4 waktu, rumput diberikan pada jam 07.00, jam 13.00 dan jam 17.00 dengan masing-masing pemberian rumput sebanyak 33,3\%, sedangkan pemberian konsentrat dilaksanakan pada jam 10.00 dengan pemberian $100 \%$ konsentrat.

\section{Tahap Pengumpulan Data}

Pengumpulan data dilakukan pada saat awal penelitian dan akhir penelitian. Menurut Heriyadi, (2012), pengumpulan data dilakukan dengan cara mengukur ukuran-ukuran tubuh yaitu lingkar dada, lebar dada, tinggi pundak, panjang badan, setiap melakukan pengukuran sifat kuantitatif dilakukan dengan 3 kali ulangan untuk mendapat nilai ukuran tubuh domba yang akurat

\section{Peubah yang Diamati}

Peubah yang diamati dihitung berdasarkan rumus menurut Alderson (1999).

1. Lingkar dada adalah rongga dada dibelakang sandi bahu (os scapula); pengukuran menggunakan pita ukur $(\mathrm{cm})$.

\section{PLD=LDx-Ldo}

Keterangan :

PLD : Pertambahan Lingkar Dada (cm)

LDx : Lingkar Dada Akhir

LDo : Lingkar Dada Awal

2. Lebar dada adalah jarak antara penonjolan sendi bahu (os scapula) kanan dan kiri; pengukuran menggunakan pita ukur $(\mathrm{cm})$.

$$
\text { PLD=LDx-Ldo }
$$

Keterangan :

PLD : Pertambahan Lebar Dada $(\mathrm{cm})$

LDx : Lebar Dada Akhir

LDo : Lebar Dada Awal

3. Tinggi pundak, jarak tertinggi pundak sampai tanah, diukur dengan menggunakan tongkat ukur dalam satuan sentimeter $(\mathrm{cm})$.

$$
\text { PTP=TPx-Tpo }
$$

Keterangan :

PTP : Pertambahan Tinggi Pundak $(\mathrm{cm})$

TPx : Tinggi Pundak Akhir

TPo : Tinggi Pundak Awal

4. Panjang badan, jarak garis lurus dari tepi tulang processus spinosus dari vertebrae thoracalis tertinggi sampai benjolan tulang tapis atau os. Ischium, diukur menggunakan pita ukur dalam satuan sentimeter $(\mathrm{cm})$.

$$
\mathrm{PPB}=\mathrm{PBx}-\mathrm{Pbo}
$$

Keterangan :

PPB : Pertambahahan Panjang Badan (cm)

PBx : Panjang Badan Akhir 


\section{Hasil dan Pembahasan}

\section{Keadaan Umum Lokasi Pemeliharaan}

Unit Pelaksanaan Teknis Daerah Balai Pengembangan Perbibitan Ternak Domba dan Kambing (UPTD BPPTDK) Margawati Garut didirikan pada tahun 1975 dengan bertujuan untuk melestarikan dan meningkatkan populasi, kualitas dan produktivitas Domba Garut sebagai domba khas Jawa Barat. Sesuai dengan fungsinya UPTD BPPTDK Margawati Garut berupaya mengembangkan ternak Domba Garut yang berkualitas unggul untuk dikembangkan kepada masyarakat luas sehingga dapat menjamin suplai bibit Domba Garut khususnya di wilayah Provinsi Jawa Barat.

UPTD BPPTDK Margawati Garut terletak di Kelurahan Margawati Kecamatan Garut Kota Kabupaten Garut Provinsi Jawa Barat, lokasi berjarak $\pm 7 \mathrm{~km}$ dari jalan provinsi atau sekitar \pm 10 km Kecamatan Garut. Secara Geografis, lokasi UPTD BPPTDK Margawati Garut berbatasan dengan wilayah sebagai berikut :

$\begin{array}{ll}\text { Sebelah Barat } & \text { : Kelurahan Sukanegla } \\ \text { Sebelah Timur } & \text { : Kampung Cipicung } \\ \text { Sebelah Selatan } & \text { : Kampung Taringgul } \\ \text { Sebelah Utara } & \text { : Kampung Panaggan }\end{array}$

Secara topografis terletak pada ketinggian 1.000 meter di atas permukaan laut (DPL), keadaan tanah berbukit dan dilalui oleh aliran sungai Ciwalen yang merupakan sumber air utama bagi balai dan masyarakat sekitar, disamping itu areal balai mempunyai lahan kritis dengan kemiringan $\pm 60^{\circ}$ seluas 2 ha. Keadaan tanah umumnya bertekstur lempengan pasir dan berdebu dengan keasaman tanah $(\mathrm{pH})$ termasuk sedang (6-7), sehingga untuk pengolahan tanah tidak perlu dilakukan pengapuran. Tanah yang akan dikelola cukup dengan dicangkul terlebih dahulu kemudian ditumpuk dengan kotoran yang berasal dari ternak domba.

Temperatur lingkungan tercatat berkisar antara $16^{\circ}-26^{\circ} \mathrm{C}$ dengan rata-rata suhu $21^{\circ} \mathrm{C}$, kelembaban udara berkisar antara $85-95 \%$ dengan rata-rata $90 \%$, sedangkan curah hujan rata-rata perhari mencapai 5,35 mm dengan rata-rata per tahun $2020 \mathrm{~mm} /$ tahun. Hal ini dapat dikatakan bahwa keadaan lingkungan tersebut cukup baik untuk peternakan. Luas seluruh areal sekitar 27 ha yang tediri dari 16 ha kebun rumput produktif, 2 ha kebun karyawan, 2 ha bangunan, 5 ha lahan belum tergarap, dan 2 ha lahan kritis. Jumlah bangunan sebanyak 26 unit yang terdiri dari 12 unit bangunan kandang, 8 unit rumah karyawan, 3 unit kantor, 1 unit aula, 1 unit gudang konsentrat dan 1 unit gudang silase.

Bangunan kandang berbentuk bangunan panggung yang terdiri dari kandang satu baris dan kandang dua baris. Kandang tersebut terdiri dari dua sistem, yaitu kandang individu dan kandang kelompok. Kandang individu digunakan untuk induk bunting tua, pejantan, dan induk menyusui, sedangkan kandang kelompok digunakan untuk domba lepas sapih, domba muda, induk kawin, dan induk bunting muda. Bahan dasar pembuatan kandang adalah kayu sedangkan lantai dan dinding kandang menggunakan papan. Bagian atap kandang menggunakan abses. Jarak dari lantai ke permukaan tanah berkisar 1-1,5 $\mathrm{m}$.

\section{Pengaruh Perlakuan terhadap Lingkar Dada}


Lingkar Dada merupakan jarak rongga dada dibelakang sandi bahu (os scapula), diukur dengan menggunakan pita ukur $(\mathrm{cm})$. Lingkar dada merupakan parameter yang cukup penting untuk ternak Domba Garut karena ukuran lingkar dada yang besar memungkinkan paru-paru lebih berkembang sehingga pernafasan menjadi lebih kuat dan panjang sehingga dapat meningkatkan produktivitas ternak.

Hasil pengukuran pertambahan ukuran lingkar dada Domba Garut jantan dari setiap perlakuan penelitian disajikan dalam Tabel 1 .

Tabel 1. Pertambahan Lingkar Dada Domba Garut Jantan

\begin{tabular}{cccc}
\hline \multirow{2}{*}{ Ulangan } & \multicolumn{3}{c}{ Perlakuan Lingkar Dada } \\
\cline { 2 - 4 } & $\mathbf{P 1}$ & $\mathbf{P 2}$ & $\mathbf{P 3}$ \\
\hline 1 & 3,8 & 8,0 & 2,8 \\
2 & 10,5 & 4,5 & 10,5 \\
3 & 9,0 & 3,5 & 10,0 \\
4 & 3,5 & 4,0 & 8,0 \\
5 & 10,0 & 4,0 & 5,0 \\
6 & 4,0 & 3,5 & 6,0 \\
\hline Total & 40,8 & 27,5 & 42,3 \\
\hline Rataan & 6,80 & 4,58 & 7,05 \\
\hline
\end{tabular}

Keterangan :

$\mathrm{P} 1=$ Ransum dengan imbangan rumput dan konsentrat $80 \%: 20 \%$

$\mathrm{P} 2=$ Ransum dengan imbangan rumput dan konsentrat $60 \%: 40 \%$

P3 = Ransum dengan imbangan rumput dan konsentrat $40 \%: 60 \%$

Secara khusus besar kecilnya lingkar dada menggambarkan bahwa ternak tersebut memiliki pernapasan yang cukup baik sehingga dapat meningkatkan peforma dan metabolisme ternak Domba Garut, dengan lingkar dada yang besar juga hal ini sangat disukai oleh peternak penggemar seni ketangkasan domba, hal ini di buktikan oleh Gunawan dkk. (2006) yang menyatakan bahwa lingkar dada berkorelasi positif terhadap skor ukuran Domba Garut. Tabel 1 menunjukan rata-rata pertambahan lingkar dada Domba Garut jantan. Hasil penelitian dari yang terendah sampai tertinggi adalah 4,58 cm(P2), 6,80 cm (P1), dan 7,05 cm (P3). Untuk mengetahui pengaruh imbangan rumput dan konsentrat terhadap lingkar dada dilakukan analisis sidik ragam. Hasil analisis sidik ragam disajikan dalam Tabel 2.

Tabel 2. Analisis Sidik Ragam Pengaruh Imbangan Rumput dan Konsentrat terhadap Ukuran Lingkar Dada Domba Garut Jantan.

\begin{tabular}{llcccl}
\hline Sumber Keragaman & $\mathrm{Db}$ & $\mathrm{JK}$ & $\mathrm{KT}$ & Fhit & F0.05 \\
\hline Perlakuan & 2 & 22,12 & 11,06 & 1,42 & 3,68 \\
Galat & 15 & 116,08 & 7,74 & & \\
\hline Total & 17 & 138,2 & 18,80 & & \\
\hline
\end{tabular}

Keterangan : $\mathrm{F}_{\text {hitung }}<\mathrm{F}_{\text {tabel }}$ artinya tidak berpengaruh nyata.

Hasil sidik ragam menunjukan bahwa perlakuan pakan yang diberikan tidak berpengaruh nyata $(\mathrm{P}<0,05)$ terhadap pertambahan lingkar dada Domba Garut jantan selama penelitian, hal tersebut dipengaruhi karena tidak tercukupinya kandungan protein dalam ransum dan mengakibatkan www.journal.uniga.ac.id 
kurangnya absorbsi atau penyerapan dalam tubuh ternak domba, sehingga dapat mengakibatkan keterlambatan atau tidak mempengaruhi pertumbuhan dalam tubuh ternak khususnya ukuran tubuh lingkar dada.

Lingkar dada merupakan ukuran tubuh yang sangat penting untuk Domba Garut yang akan memiliki adeg-adeg yang baik untuk domba tipe tangkas oleh karena itu sangat penting untuk melakukan penelitian ukuran lingkar dada domba. Selain itu bentuk lingkar dada juga berperan penting bagi skor ukuran Domba Garut, dengan di buktikan oleh Gunawan dkk, (2006) yang menyatakan bahwa lingkar dada berkorelasi positif terhadap skor ukuran pada Domba Garut, hal ini membuktikan bahwa ukuran tubuh lingkar dada sangat berperan penting terhadap ukuran tubuh domba. Mulliadi (1996) melaporkan bahwa rataan lingkar dada adalah 61,34 $\pm 5,75 \mathrm{~cm}$ pada domba lokal Garut umur 1-5 tahun, namun berbeda nyata dengan hasil penelitian yang dilakukan, yaitu berkisar 27,5 - 42,3 perbedaan angka ini menunjukkan karena berbedaan usia ternak dan jenis ternak yang di teliti.

\section{Pengaruh Perlakuan terhadap Lebar Dada}

Konsumsi pakan erat kaitannya dengan pertambahan ukuran tubuh, salah satunya lebar dada. Lebar dada merupakan gambaran bahwa organ-organ respirasi dan jantung tumbuh dengan baik yang akan menunjang pembentukan energi anaerob berjalan baik sehingga akan meningkatkan metabolisme dalam tubuh ternak domba. Hasil pengukuran pertambahan lebar dada Domba Garut jantan dari setiap perlakuan penelitian disajikan pada Tabel 3.

Tabel 3. Pertambahan Lebar Dada Domba Garut Jantan

\begin{tabular}{cccc}
\hline \multirow{2}{*}{ Ulangan } & \multicolumn{3}{c}{ Perlakuan Lebar Dada } \\
\cline { 2 - 4 } & P1 & P2 & P3 \\
\hline 1 & 1,5 & 1,2 & 1,2 \\
2 & 2,0 & 1,0 & 2,5 \\
3 & 1,5 & 1,7 & 4,0 \\
4 & 1,2 & 1,0 & 3,0 \\
5 & 1,5 & 1,0 & 2,0 \\
6 & 3,2 & 1,0 & 1,4 \\
\hline Total & 10,9 & 6,9 & 14,1 \\
\hline Rataan & 1,82 & 1,15 & 2,35 \\
\hline
\end{tabular}

Hasil penelitian lebar dada dari yang terendah sampai tertinggi adalah $1,15 \mathrm{~cm}(\mathrm{P} 2), 1,82 \mathrm{~cm}(\mathrm{P} 1)$, dan 2,35 cm (P3). Untuk mengetahui pengaruh imbangan rumput dan konsentrat terhadap lebar dada dilakukan uji analisi ragam. Uji analisis ragam tertera pada Tabel 4.

Tabel 4. Analisis Sidik Ragam Pengaruh Imbangan Rumput dan Konsentrat terhadap Ukuran Lebar Dada Domba Garut Jantan

\begin{tabular}{lcllll}
\hline Sumber Keragaman & $\mathrm{Db}$ & $\mathrm{JK}$ & $\mathrm{KT}$ & Fhit & F0.05 \\
\hline Perlakuan & 2 & 4,33 & 2,16 & 3,81 & 3,68 \\
Galat & 15 & 8,53 & 0,569 & & \\
\hline Total & 17 & 12,86 & 2,72 & & \\
\hline
\end{tabular}

Keterangan : $F_{\text {hitung }}>F_{\text {tabel }}$ artinya berpengaruh nyata. 
Hasil sidik ragam menunjukan bahwa perlakuan pakan yang diberikan berpengaruh nyata $(\mathrm{P}>0,05)$ terhadap pertambahan lebar dada Domba Garut jantan selama pemeliharaan, selanjutnya untuk mengetahui perbedaan antar perlakuan maka dilakukan uji jarak berganda Duncan. Hasil uji jarak berganda Duncan disajikan dalam Tabel 5.

Tabel 5. Hasil Uji Jarak Berganda Duncan Pengaruh Perlakuan terhadap Lebar Dada Domba Garut Jantan

\begin{tabular}{ccc}
\hline Perlakuan & Rataan $(\boldsymbol{\%})$ & $\begin{array}{c}\text { Signifikasi } \\
(\mathbf{0 , 0 5})\end{array}$ \\
\hline P2 & 1,15 & $\mathrm{a}$ \\
P1 & 1,82 & $\mathrm{ab}$ \\
P3 & 2,35 & $\mathrm{~b}$ \\
\hline
\end{tabular}

Keterangan : Huruf yang berbeda pada kolom signifikasi menunjukan berbeda nyata $(\mathrm{P}<0,05)$

Berdasarkan Tabel 10. Pertambahan lebar dada pada P2 tidak menunjukan perbedaan dengan P1, demikian juga P1 tidak menunjukan perbedaan dengan P3, namun demikian P2 menunjukan perbedaan yang nyata lebih rendah lebar dadanya dibandingkan dengan P3, hal ini tidak luput dari pemberian ransum yang membuat tercukupinya kebutuhan protein dalam tubuh ternak sehingga dapat memberikan asupan protein kedalam tubuh khususnya mikroorganisme.

Mikroorganisme berperan penting bagi domba khususnya pertubuhan ternak domba terutama lebar dada, ketika mikroorganisme kebutuhannya tercukupi akan dipecah menjadi zat zat yang membantu pertumbuhan ternak dan akan mempercepat absorsi atau penyerapan oleh tubuh ternak sehingga akan meningkatkan atau mempercepat pertumbuhan domba khususnya ukuran tubuh ternak. Lebar dada juga menjadi salah satu seleksi untuk menentukan kualitas domba hal ini dibuktikan oleh Riwantoro (2005) yang menyatakan seleksi terhadap ukuran tubuh pada Domba Garut seperti lebar dada telah dilakukan oleh peternak terutama dalam proses seleksi Domba Garut tangkas.

\section{Pengaruh Perlakuan terhadap Pertambahan Tinggi Pundak}

Tinggi pundak merupakan jarak tertinggi pundak sampai tanah, diukur dengan menggunakan tongkat ukur dalam satuan sentimeter $(\mathrm{cm})$. Tinggi pundak merupakan salah satu parameter yang cukup penting dalam melakukan penilaian terhadap performa dan potensi genetik ternak. Hasil pengukuran pertambahan ukuran tinggi pundak Domba Garut betina dari setiap perlakuan penelitian disajikan dalam Tabel 6.

Tabel 6. Pertambahan Tinggi Pundak Domba Garut Jantan

\begin{tabular}{cccc}
\hline \multirow{2}{*}{ Ulangan } & \multicolumn{3}{c}{ Perlakuan Tinggi Pundak } \\
\cline { 2 - 4 } & P1 & P2 & P3 \\
\hline 1 & 9,7 & 1,8 & 7,0 \\
2 & 11,6 & 1,2 & 12,7 \\
3 & 11,7 & 4,0 & 7,0 \\
4 & 2,4 & 1,0 & 5,1 \\
5 & 7,7 & 6,3 & 6,6 \\
6 & 1,2 & 13,0 & 8,0 \\
\hline Total & 44,3 & 27,3 & 46,4 \\
\hline Rataan & 7,38 & 4,55 & 7,73 \\
\hline www.journal.uniga.ac.id & & & 112
\end{tabular}


Secara khusus tinggi pundak menggambarkan bahwa pertumbuhan seekor ternak dengan melihat perkembangan tulang-tulang pipa, diantaranya Os Humerusulna, Os Metatarsus dan Os Tarsus. Untuk domba domba tipe pedaging tidak diharapkan domba tinggi, karena bagian kaki depan dan belakang tidak termasuk untuk penilaian karkas (Nurfaridah, dkk 2009). Tabel 6 menunjukan rata-rata pertambahan tinggi pundak Domba Garut jantan. Hasil penelitian dari yang terendah sampai tertinggi adalah 4,55 $\mathrm{cm}(\mathrm{P} 2), 7,38 \mathrm{~cm}(\mathrm{P} 1)$, dan 7,73 cm (P3). Untuk mengetahui pengaruh imbangan rumput dan konsentrat terhadap tinggi pundak dilakukan analisis sidik ragam. Analisis sidik ragam tertera pada Tabel 7.

Tabel 7. Analisis Sidik Ragam Pengaruh Imbangan Rumput dan Konsentrat terhadap Ukuran Tinggi Pundak Domba Garut Jantan.

\begin{tabular}{llrlcl}
\hline $\begin{array}{l}\text { Sumber } \\
\text { Keragaman }\end{array}$ & Db & JK & KT & Fhit & F0.05 \\
\hline Perlakuan & 2 & 36,56 & 18,28 & 1,118 & 3,68 \\
Galat & 15 & 245,13 & 16,34 & & \\
\hline Total & 17 & 281,69 & 34,62 & & \\
\hline
\end{tabular}

Keterangan : $\mathrm{F}_{\text {hitung }}<\mathrm{F}_{\text {tabel }}$ artinya tidak berpengaruh nyata.

Hasil sidik ragam menunjukkan bahwa perlakuan pakan yang diberikan tidak berpengaruh nyata $(\mathrm{P}<0,05)$ terhadap pertambahan tinggi pundak selama pemeliharaan. Selama pertumbuhan, tulang tumbuh secara kontinyu dengan kadar laju pertumbuhan yang relatif lambat, sehingga rasio otot dengan tulang meningkat selama pertumbuhan (Soeparno, 1992), kekurangan pertumbuhan tersebut dikarenakan kurangnya kandungan ransum yang mempengaruhi keterlambatan dalam pertumbuhan hal ini buktikan oleh Wiradisastra dan Usri (1980) menyatakan bahwa kekurangan energi dan protein dalam ransum akan menghambat pertambahan bobot hidup. Perlakuan P2 secara kualitas belum dapat memenuhi kebutuhan untuk pertumbuhan walaupun secara kuantitas (konsumsi) mencukupi. Rumput dan konsentrat pada ransum P2 masih dibawah kebutuhan domba yang sedang tumbuh, sedangkan menurut (Edey, 1983) energi merupakan pembatas utama terhadap sistem produksi hewan, kemudian protein, mineral dan vitamin.

Tinggi pundak merupakan salah satu bagian dari domba ketangkasan yang menunjang kecekatan dan ketepatan dalam adu ketangkasan hal ini dibuktikan oleh Mulliadi (1996) yang menyatakan bahwa Domba Garut tipe tangkas memiliki ukuran pundak yang lebih tinggi jika dibandingkan bagian tengah tubuh atau perut dan bagian pinggul. Hal ini karena pada saat beradu, kepala harus tepat beradu dengan kepala lawan, oleh karena itu perlu ditunjang tinggi pundak dan kaki yang besar dan kuat, kelincahan dan keserasian tubuh.

\section{Pengaruh Perlakuan terhadap Panjang Badan}

Konsumsi pakan erat kaitannya dengan pertambahan ukuran ukuran tubuh, salah satunya panjang badan. Panjang badan merupakan ukuran yang dapat digunakan untuk menduga bobot badan. Panjang badan menunjukkan kapasitas badan, yang selanjutnya akan mempengaruhi karkas sehingga dapat digunakan untuk menaksir kekompakan tubuh domba. Menurut Ensminger (1991), panjang badan menunjukan kapasitas, kekuatan dan kemampuan konsumsi pakan. Badan harus berbentuk kotak, lurus, berisi, seimbang, rusuk yang dalam dan lebar serta ukuran yang panjang sesuai umur. 
Hasil pengukuran pertambahan panjang badan Domba Garut jantan umur lima sampai delapan bulan dari setiap perlakuan penelitian disajikan pada Tabel 8 .

Tabel 8. Pertambahan Panjang Badan Domba Garut Jantan

\begin{tabular}{cccc}
\hline \multirow{2}{*}{ Ulangan } & \multicolumn{3}{c}{ Perlakuan Panjang Badan } \\
\cline { 2 - 4 } & P1 & P2 & P3 \\
\hline 1 & 8,0 & 7,1 & 8,0 \\
2 & 5,5 & 6,0 & 5,0 \\
3 & 9,0 & 2,6 & 14,2 \\
4 & 5,0 & 3,3 & 9,0 \\
5 & 10,2 & 4,0 & 9,7 \\
6 & 6,0 & 6,0 & 9,3 \\
\hline Total & 43,7 & 29 & 55,2 \\
\hline Rataan & 7,28 & 4,8 & 9,20 \\
\hline
\end{tabular}

Hasil penelitian panjang badan dari yang terendah sampai tertinggi adalah 4,83 cm (P2), 7,28 cm $(\mathrm{P} 1)$, dan 9,20 cm (P3). Untuk mengetahui pengaruh imbangan rumput dan konsentrat terhadap panjang badan dilakukan analisis sidik ragam. Hasil sidik ragam tertera pada Tabel 9.

Tabel 9. Analisis Sidik Ragam Pengaruh Imbangan Rumput dan Konsentrat terhadap Ukuran Panjang Badan Domba Garut Jantan.

\begin{tabular}{llrlrl}
\hline Sumber keragaman & Db & JK & KT & Fhit & F0.05 \\
\hline Perlakuan & 2 & 57,48 & 28,74 & 5,24 & 3,68 \\
Galat & 15 & 82,28 & 5,485 & & \\
\hline Total & 17 & 139,76 & 34,225 & & \\
\hline
\end{tabular}

Keterangan : $F_{\text {hitung }}>F_{\text {tabel }}$ artinya berpengaruh nyata.

Hasil sidik ragam menunjukkan bahwa perlakuan pakan yang diberikan berpengaruh nyata $(\mathrm{P}>0,05)$ terhadap pertambahan panjang badan domba selama pemeliharaan, selanjutnya untuk mengetahui perbedaan antar perlakuan maka dilakukan uji jarak berganda Duncan. Hasil uji jarak berganda Duncan disajikan dalam Tabel 10.

Tabel 10. Hasil Uji Jarak Berganda Duncan Pengaruh Perlakuan terhadap Panjang Badan Domba Garut Jantan.

\begin{tabular}{ccc}
\hline Perlakuan & Rataan $(\%)$ & $\begin{array}{c}\text { Signifikasi } \\
(0,05)\end{array}$ \\
\hline P2 & 4,83 & $\mathrm{a}$ \\
P1 & 7,28 & $\mathrm{ab}$ \\
P3 & 9,20 & $\mathrm{~b}$ \\
\hline
\end{tabular}

Keterangan : Huruf yang berbeda pada kolom signifikasi menunjukkan berbeda nyata $(\mathrm{P}<0,05)$

Berdasarkan Tabel 10. Pertambahan panjang badan pada P2 tidak menunjukan perbedaan dengan P1, demikian juga P1 tidak menunjukan perbedaan dengan P3, namun demikian P2 menunjukan perbedaan yang nyata lebih rendah panjang badannya dibandingkan dengan P3, tingginya pertambahan panjang badan pada P3 dimungkinkan karena tercukupinya kebutuhan protein dan 
energi yang dikonsumsi oleh domba tersebut, sehingga menghasilkan pertambahan bobot badan, yang diikuti dengan pertambahan panjang badan.

Hasil penelitian menunjukan bahwa pertambahan panjang badan dipengaruhi oleh imbangan rumput dan konsentrat dalam ransum. Ransum dengan imbangan konsentrat tertinggi menghasilkan pertambahan panjang badan tertinggi, yaitu P3 dengan konsentrat sebesar $60 \%$ dibandingkan dengan perlakuan P2 dengan imbangan konsentrat 40\%. Ternak memiliki kebutuhan protein yang sesuai dengan umur, jenis ternak, dan jenis kelamin. Ransum dengan konsentrat tertinggi menyebabkan ternak mendapatkan asupan protein yang cukup bagi tubuh. Peningkatan kadar protein ransum akan meningkatkan ketersediaan asam amino dalam tubuh, yang salah satunya digunakan untuk pertumbuhan (Puastuti W, 2005). Hal ini digambarkan oleh ternak yang mendapatkan perlakuan P2 dengan pertambahan ukuran panjang badan yang terendah dibandingkan dengan ternak yang mendapatkan perlakuan ransum lain.

Rendahnya pertambahan ukuran panjang badan akan berpengaruh terhadap bobot badan, hal tersebut bersesuaian dengan pendapat Rehfeldt dkk., (2004) bahwa panjang badan dijadikan parameter dalam pendugaan bobot badan seekor ternak. Pertumbuhan pada domba bukanlah sekedar pertambahan beratnya saja, namun berhubungan erat dengan perbandingan tinggi dan panjang badannya. Soeparno (1992) menyatakan rasio otot dan tulang selalu meningkat selama pertumbuhan.

Penggunaan ukuran panjang badan untuk suatu aktivitas pengadaan ternak dalam suatu kegiatan tertentu, memiliki beberapa kelebihan dibanding dengan dasar bobot badan, karena pengukuran panjang badan lebih mudah dilakukan dibandingkan pengukuran bobot badan, di samping itu pengukuran panjang badan relatif tidak akan banyak berubah akibat adanya variasi atau mismanagement dalam pemeliharaan untuk jangka waktu yang cukup panjang, sehingga akan mengeliminasi kemungkinan konflik antara peternak, rekanan, pemasok, maupun badan pemeriksa tertentu untuk aktivitas yang sedang berjalan.

\section{Kesimpulan}

Berdasarkan hasil penelitian dengan judul pengaruh imbangan rumput dan konsentrat terhadap ukuran tubuh Domba Garut jantan umur lima sampai delapan bulan dapat diambil kesimpulan bahwa :

1. Imbangan rumput dan konsentrat dalam ransum mempengaruhi terhadap ukuran tubuh Domba Garut.

2. Imbangan rumput dan konsentrat sebesar 40\%:60\% dalam ransum P3 menghasilkan pertambahan lebar dada dan panjang badan tertinggi pada Domba Garut Jantan umur lima sampai delapan bulan.

\section{Daftar Pustaka}

Alderson G. L. 1999. The Development of a System of Linear Measurements to Provide an Assessment of Type and Fuction of Beef Cattle. Animal Genetic Resources information.

Direktorat Jendral Peternakan dan Kesehatan Hewan. 2018. Populasi Domba MenurutProvinsi.Jakartahttp://www.bps.go.iddynamictable/2015/12/17\%2000;00;00/1 024/populasi-domba-menurut-provinsi-2009-2018.html 
Edey TN. 1983. Lactation, Growth and Body Composition In : Tropical Sheep and Goat Production. T. N. Edey (ed) Melbourne: The Dominion Press- Hedges \& Bell Pry. Ltd. Page : 81-108.

Ensminger, M. E. 1991. Animal Science. $9^{\text {th }}$ Edition. Interstate Publishers Inc., Danville, Illinois

Gunawan A dan RR Noor. 2006. Pendugaan Nilai Campuran Fenotif dan Jarak Genetik Domba Garut Tipe Laga. Med. Peternakan

Heriyadi, D.2012. Modul I Produksi Domba dan Kambing. Laboraturium Produksi Ternak Potong. Fakultas Peternakan Universitas Padjadjaran. Bandung.

Mulliadi. 1996. Sifat fenotifik domba Priangan di kabupaten Pandeglang dan Garut. Disertai Program Studi Pascasarjana. Institut Pertanian Bogor, Bogor.

B. K., dan Siti N. 2009. Indeks Kumulatif Ukuran-Ukuran Tubuh dan Bobot Badan Domba Komposisi Betina Dewasa sebagai Domba Pedaging. (Studi Kasus di Kandang Percobaan Fakultas Peternakan Universitas Padjajaran)

Puastuti, W. 2005. Tolak Ukur Mutu Protein Ransum dan Relevensinya dengan Retensi Nitrogen serta Pertumbuhan Domba. Disertasi. Sekolah pascasarjana, Institut Pertanian Bogor.

Rehfeldt, C., I. Fieldier, and N. C. Sticland. 2004. Numbering Size of Muscle Fibrous in Relation to Meat Production. In : Everts M. E. M. W. F. TePas, H. P. Haagsmant (ed). Muscle Develovment of Livestock Animal Physologi. Genetic and meat Quality. CABI Publishing.

Riwantoro. 2005. Konservasi Plasma Nutfah Domba Garut Dan Strategi Pengembangannya Secara Berkelanjutan. Disertasi. Fakultas Pascasarjana Institut Pertanian Bogor, Bogor.

Soeparno. 1992. Ilmu dan Teknologi Daging. Cetakan Ketiga. Gadjah Mada University Press, Yogyakarta.

Wiradisastra, D. H. dan T. Usri. 1980. Kebutuhan Zat Makanan Untuk Domba. Fakultas Peternakan Universitas Padjajaran. Bandung. 